\title{
Professional competence of teachers in Indian higher agricultural education
}

\author{
P. Ramesh* and P. Krishnan
}

Education is the backbone for the growth and development of a nation. As India is an agrariandominated economy, agricultural education plays an important role in providing human resources for improving agricultural productivity and natural resource management in a sustainable manner. The competence and performance of teachers are the key factors determining the quality of any educational programme. The current higher education sector in general and that of the agricultural sector in particular, is facing many critical challenges, including the quality of teaching. Identification of the key competences and characteristics of an effective teacher is essential for the selection, recruitment and in-service training of teachers. This article reviews the studies on teaching competences, covering the various dimensions, with special reference to agricultural education. The study calls for developing an appropriate competence framework to deliberate on the effectiveness of teachers, adjudge and prioritize areas for professional growth and development, and aid in planning their personal and career development. Strategies to enhance the competence of teachers so as to improve the quality of teaching in agricultural universities are also discussed.

Keywords: Agricultural education, professional competence, teacher training, human resources.

THE domain of education in the recent era has undergone a sea change with the infusion of technology in all walks of life, including that of teaching. As rightly remarked by Kress $^{1}$, the focus of education in the previous era was for stability, whereas the current and future need is an education for instability. This paradigm shift lays significant stress on the professional development of the teachers so as to stay relevant to the ever-evolving needs. With the changing contours of expectations of learners, the aims of education also change, thus warranting a corresponding change in the competences of the teachers, which is particularly so in higher education. The average span of the service of a teacher in higher education is about 30 years, a period which is long enough to witness wholesome changes in the demands on the content and delivery of education. However, the mechanisms to instill matching skills among the teachers based on a comprehensive assessment of the inherent competences against those required at a given point of time, have not been institutionalized. Thus, by inference, the students of a particular era get to be taught by teachers whose competences, in all

P. Ramesh is in the Division of Human Resource Management and P. Krishnan is in the Division of Research Systems Management at ICAR-National Academy of Agricultural Research Management (NAARM), Rajendranagar, Hyderabad 500 030, India.

*For correspondence. (e-mail: pramesh.icar@gmail.com) likelihood, do not match with the contemporary needs. This calls for reinvigorating the mechanism of assessing the competences of teachers depending on the evolving needs of human development and education.

Teaching is a complex, multifaceted and value-laden enterprise in a knowledge-oriented society. A good teacher should be a life-long learner, and education and learning of teachers are fundamental aspects to achieve this ${ }^{2,3}$. The experts, policy makers and educational reformers differ in their perspective regarding what is important in teacher preparation and where or how they can be acquired, as these vary depending on the prior knowledge of teachers ${ }^{4}$. Also, teachers should strive to update their levels of knowledge and skills in order to improve their teaching efficiency. Many of the studies on competences of teachers focus on their performance in the classroom, rather than their core competences required for the profession. The ambit of competences of teachers has broadened to cover reforms in education, teacher education, pedagogical knowledge and other related fields.

The trait and factor theory of Parsons ${ }^{5}$ postulates that the success and happiness of a person in his/her career depend upon three factors, viz. (i) the person's psychological traits; (ii) competencies needed for any profession, and (iii) the extent of match between (i) and (ii). This theory emphasizes that if the inherent competencies of an individual match with those required for a professional job, then the individual would perform to his/her 
best with highest productivity levels. Thus, understanding the competences and traits required for a successful teacher, and periodic assessment and enhancement of the competences of teachers are critical to ensure quality teaching.

\section{What is teacher competence?}

The terms, 'competence' and 'competency' are used interchangeably, and more often incorrectly. Competence is an array of abilities across domains related to performance in a specific context, whereas competency concerns a particular ability ${ }^{6-8}$. Competence is a task-related capability or outcome, while competency is the individual state of orientation ${ }^{9}$. Competence is a comprehensive concept for abilities or capabilities of people or organizations, while a specific competency forms a part of competence ${ }^{10}$

In this context, it is appropriate to distinguish 'teaching competences' and 'teacher competences'. Teaching competences relate to the craft of teaching and thus pertain to the actions of a teacher in the classroom. Teacher competences would include the multifaceted roles of teachers in different levels, i.e. individual, school, local community and professional networks, covering the entire gamut of their profession. Thus, the latter is wider in scope and includes the former ${ }^{11}$.

Figure 1 depicts a general framework on competencies of teachers, including nine different dimensions as adopted from Selvi ${ }^{12}$.

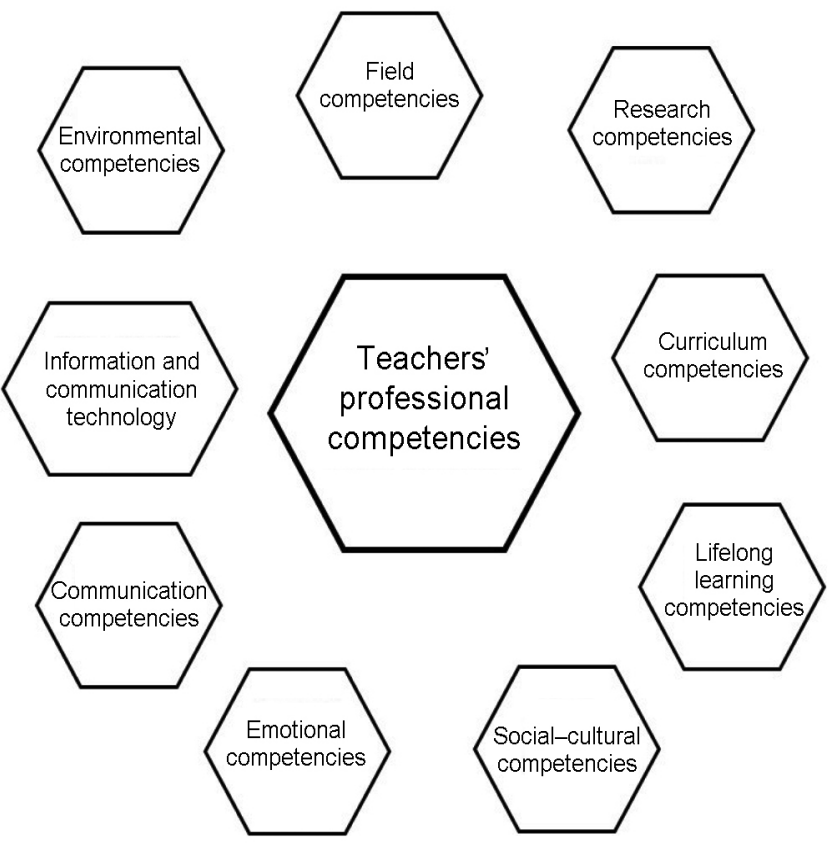

Figure 1. Components of professional competencies of teachers (adopted from Selvi ${ }^{12}$ ).

\section{Importance of teacher competence}

It is well recognized that teacher competence has a strong correlation with teaching effectiveness ${ }^{13}$. Teacher competences, like professional knowledge, skills, beliefs and motivation serve as critical predictors of their well-being and success ${ }^{14,15}$. The competencies of teachers are influenced by their values, perception and belief systems on teaching during their teacher-training programme ${ }^{16-20}$. Teachers acquire their professional competencies through various means, viz. self-study, training programmes for their professional development, cross-learning through peers and initial teacher education ${ }^{21,22}$.

The pedagogical content knowledge, professional beliefs, self-motivation, passion for teaching and the ability of teachers to maintain instructional quality contribute to their professional competence more than their subject knowledge and also in positively influencing the learning outcome of their students ${ }^{23}$.

\section{Teacher competence assessment}

The main aim of human resource management is to assess the competences essential for a specific job and position. There is a need to identify the competency gaps through mapping the difference between acquired and required competences. Appropriate quantitative and mathematical approaches or models are required for accurately assessing the competences, which can be used in different sectors and fields ${ }^{24}$, and aid in collection and appraisal of evidences ${ }^{25,26}$. Though competency frameworks can fulfill a useful function in focusing on the development of expertise in pedagogical practice, they rarely offer scope for consideration of factors beyond the classroom or educational institutions, which impacts educational success, and thus caution must be exercised in the use of competency frameworks for teacher assessment ${ }^{27}$.

Francesca $^{28}$ analysed the relevance of teacher competencies in relation to educational reforms in the context of European education systems and emphasized the need for the development of teacher competence frameworks in order to improve the quality of teacher education and their continuous professional development.

\section{Teacher competence in agricultural education: a global perspective}

Shortage of well-qualified teachers to fill the current and emerging vacancies in higher educational institutions is one of the important issues confronted by agricultural education $^{29}$. Teaching competency of the faculty primarily decides the quality of education in agriculture. The other factors which influence educational quality include enabling environment, guiding philosophy, institutional commitment, quality initiatives, dissemination methods and 
assessment process. Teacher education across the levels must be mainstreamed into the academic life of our institutions so as to make the teachers more effective and efficient ${ }^{30}$.

The faculty members in the agricultural higher education system need in-service education pertaining to teaching-learning. Historically, in-service programmes have been conducted to assist agricultural teachers, especially for those in their early career, to impart knowledge and skills necessary to perform their teaching roles ${ }^{31}$. It is imperative to conduct in-serve training needs assessment for agriculture educators, both under formal ${ }^{32-36}$ and nonformal settings ${ }^{37,38}$.

The characteristics of effective teachers in agricultural education extends beyond classroom teaching. The curriculum broadly covers diverse aspects, including crop production and protection, natural resource management, harvest and post-harvest technologies, value addition and marketing, and relevant basic sciences. Agricultural education is delivered through three interconnected components: (i) classroom or laboratory instruction; (ii) experiential learning, which usually takes place outside the classroom through a structured programme, under the supervision of an instructor, and (iii) leadership education $^{39}$. Agricultural science teachers serve in the higher education institutions and have diverse roles like guiding student projects, advising student organizations, managing adult students groups, and to facilitate planning and coordinating agricultural science programmes ${ }^{40}$.

The national standards for teacher education developed by the American Association for Agricultural Education $^{41}$, suggests that the pre-service teacher education programme in agricultural science education should have a balanced curriculum comprising general education concepts, agriculture subject knowledge, pedagogy and professional skills. Roberts et al. ${ }^{42}$ identified 47 unique traits and competences necessary for successful agricultural

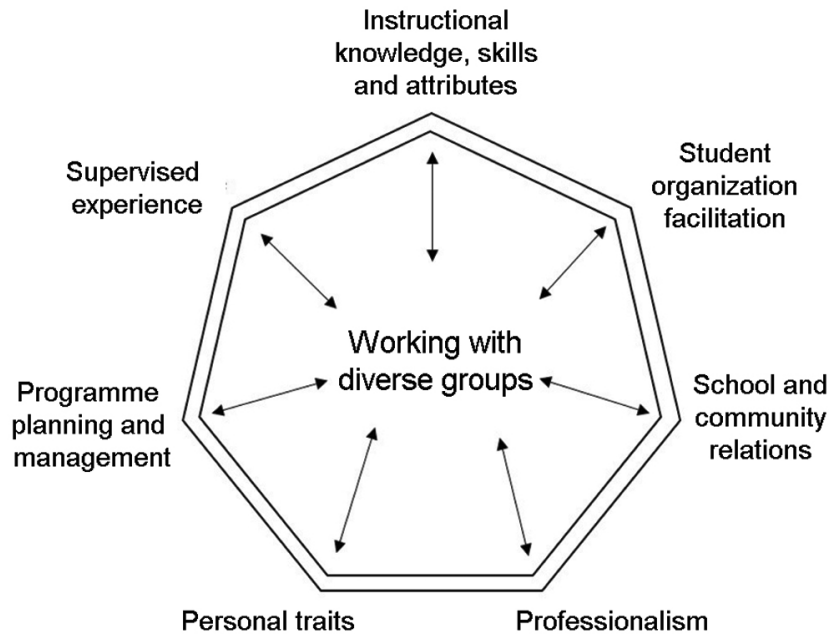

Figure 2. Model of competencies and traits of successful agricultura science teachers (adopted from Roberts et $a l .{ }^{42}$ ). science teachers and grouped them into seven categories. The heptagon model (Figure 2) depicts the interaction among these competences and with the central competence, viz. 'working with diverse groups'.

It is important to undertake professional development activities for faculty members in agriculture and life sciences to instill competencies related to (a) engaging students in learning; (b) imparting critical thinking; (c) effective lecturing; (d) inquisitive questioning, and (e) effective learning strategies ${ }^{43}$. There is a need to integrate the concepts of sustainability in the agricultural curriculum and strengthen the problem-solving and decisionmaking skills of students, thus making them think critically and creatively by understanding their learning styles and behavioural issues ${ }^{44}$.

\section{Teacher competence in Indian agricultural education}

There are 64 State Agricultural Universities, three Central Agricultural Universities, four Deemed Universities and four Central Universities with agriculture faculty in India, the course curriculum and structure, of which are governed centrally by the Indian Council of Agricultural Research (ICAR). At present, there are 650 agricultural colleges in the country offering higher education in agriculture and allied sciences, which admit about 40,000 students at different levels ${ }^{45}$. There are about 20,000 faculty members, specialized in about 90 different disciplines of agricultural sciences covering domains like horticulture, animal sciences, fisheries, engineering and social sciences. A vast majority of faculty are alumni of one of these institutions of higher learning ${ }^{46}$.

The manpower developed by agricultural educational institutions has played a significant role in the overall transformation of agriculture in India ${ }^{29}$. However, agricultural education in India is confronted with many challenges in developing human resources in order to solve the problems of improved agricultural productivity, sustainable management of natural resources, climate change, etc. ${ }^{47}$. In view of the above problems, the significance of building the competences of faculty members of agricultural universities to generate future-ready students cannot be undermined ${ }^{45}$.

In spite of the best efforts made by both ICAR and agricultural universities, the present Indian higher agricultural education sector is facing many critical challenges, such as inadequate and substandard quality of human resource, inadequacy in funding, declining quality of education, weaknesses in teaching-learning processes, etc. $^{29,48}$.

The competence and performance of teachers play a significant role in determining the quality of teaching and hence educational programmes. The teaching quality inherently depends on the values, aptitude and attitude of 
the teachers. Teaching is a dynamic activity with strong subjective aspects, and is influenced by individual and collective philosophy and values ${ }^{49}$. Studies on teacher competence, development and implementation of competence framework for teachers in the Indian higher educational systems are limited compared to other parts of the world, viz. Europe ${ }^{25,28}$, Australia ${ }^{50}$, Hong Kong ${ }^{51}$ and $\mathrm{USA}^{41}$. Identification of a list of competences and traits of an effective teacher is essential for their selection, recruitment and in-service training. However, there are limited studies on the personality traits and teaching competences of the faculty working in Indian agricultural universities.

The number of women among the scientific staff and those from urban background is on the rise in the recent years and faculty members serving in the agricultural education system in India have a largely satisfactory career growth. Few concerns for the sector are inadequate training opportunities, devotion of more time in administration at the cost of teaching and research by the senior scientific staff, and inappropriate recruitment policies in state Agricultural Universities which provide for more localized selection ${ }^{52}$.

A recent national study conducted on the teaching aptitude and personality characteristics of about 500 faculty members of different Agricultural universities in India showed that $28.8 \%$ of faculty have 'average' to 'low' level of teaching aptitude, warranting institutionalization of need-based capacity building programmes for them ${ }^{53}$. The prioritized teaching competences for the newly recruited faculty members of agricultural universities in India are 'getting students engaged in learning', 'mentoring undergraduate students', 'teaching in practical settings', 'using web-based technologies for managing courses' and 'effective teaching fundamentals, ${ }^{54}$.

Academic achievement and teaching aptitude, together serve as a better indicator for teaching achievement than

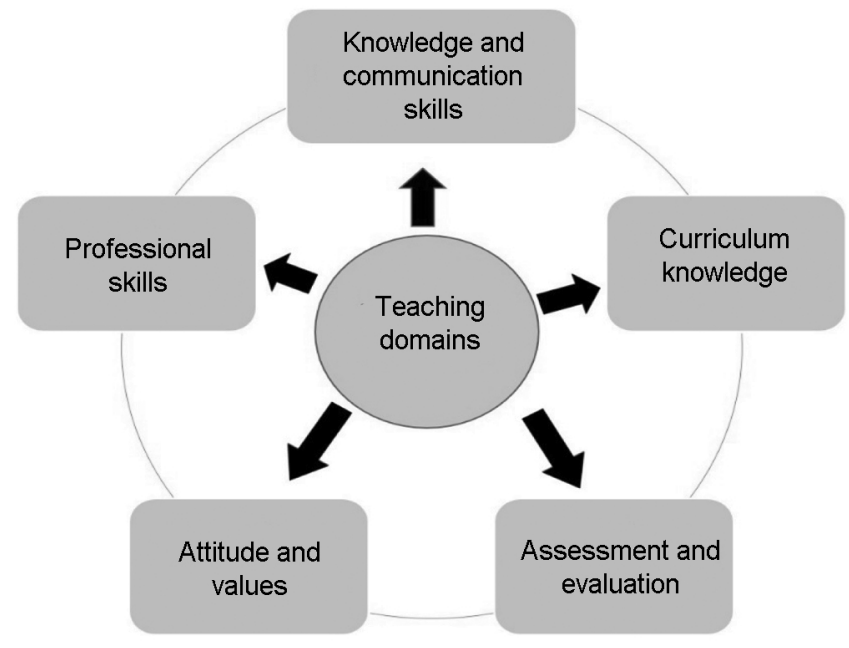

Figure 3. Model of teaching competencies for faculty of agricultural universities in India ${ }^{56}$. either of them alone ${ }^{55}$. Competency need assessment of faculty members should be done at all levels, i.e. young, mid-career and senior ${ }^{56}$, so as to improve their interpersonal, team-building and leadership skills. This would improve their overall personality and enhance their commitment to the organization. A study conducted among the entry-level agricultural scientists $(n=550)$ recruited by ICAR, who possess similar qualification as any entrylevel agricultural faculty, at the beginning of their Foundation Course at ICAR-NAARM, showed that $25.2 \%$ of scientists have 'unfavourable' attitude towards research as against $44.7 \%$ who have 'moderately favourable' attitude; only $30.1 \%$ were found to have 'above average' attitude towards research and research-related activities ${ }^{57}$. This reflects the characteristics of the overall pool of postgraduates in agricultural sciences, as the qualifications of the entry-level scientists in ICAR and those of the entry-level faculty members of agricultural universities are similar. This highlights the challenge in identifying the agricultural graduates with reasonable aptitude for research from among the potential aspirants, and the need for a comprehensive foundation course for the freshly recruited faculty members.

The key areas in which the faculty members of Indian agricultural universities require to improve their skills, as determined based on a study with 28 pre-identified teaching competencies are: knowledge and application of teaching strategies and skills, motivating the students through different teaching methods, positive attitude towards students, importance of life-long learning and updating of subject-matter knowledge ${ }^{56}$. The authors ${ }^{56}$ provided a framework for assessing these teaching competencies $(n=28)$, which were re-classified into five teaching domains, as presented schematically in Figure 3 .

\section{Conclusion}

The present study highlights the need for developing a frame work for ascertaining the gap between the acquired and desired teaching competences in the agricultural higher education sector. Accordingly, appropriate strategies are to be evolved for faculty development so as to aid in effective teaching and improving higher education quality. Understanding the major problems confronted by the entry-level teachers in agriculture education would aid in designing an appropriate pre-service teacher education programme for preparing the potential teachers ${ }^{58}$. This is essential for ensuring that the graduates of the pre-service programmes would possess competences and traits as required for successful agricultural science teachers. Further, training needs assessment should be institutionalized in order to periodically profile the shifts in the needs as faculty members advance in their careers, possibly due to professional development activities or other factors. 
The ICAR-NAARM has designed a month-long foundation course exclusively for faculty members of agricultural universities in India. Further, ICAR has taken various initiatives for strengthening the physical and human resources, and to enhance the competences of teachers under the National Agricultural Higher Education Project, supported by World Bank. Recognizing the significance and influence of teacher competence for imparting knowledge and skill among agricultural students, a national pre-service module must be designed, which could be offered through an appropriate medium leveraging information technology. Such a programme focusing on enhancing teaching competence, based on an assessment of the innate strengths (teaching and research aptitude), shall be integrated into the National Eligibility Test of ICAR, which currently tests only the subject knowledge of potential aspirants for appointment as faculty members in agricultural universities in India.

1. Kress, G., A curriculum for the future. Cambridge J. Educ., 2000, 30(1), 133-145.

2. Feiman-Nemser, S., From preparation to practice: designing a continuum to strengthen and sustain teaching. Teach. Coll. Rec., 2001, 103(6), 1013-1055.

3. McDiarmid, G. W. and Clevenger, B.M., Rethinking teacher capacity. In Handbook of Research on Teacher Education (eds Cochran-Smith, M., Feiman-Nemser, S. and Mc Intyre, D.), Enduring Questions in Changing Contexts, New York/Abingdon, Routledge/Taylor \& Francis, USA/UK, 2008.

4. Schwille, J. and Dembélé, M., Global perspectives on teacher learning: improving policy and practice. UNESCO, Paris, 2007.

5. Parsons, F., Choosing a Vocation, National Career Development Association, Broken Arrow, 1989, Oklahoma, USA, ISBN 10: 1885333145/ISBN 13: 9781885333148

6. Frank, J. R., Snell, L. S. and Cate, O. T., Competency-based medical education: theory to practice. Med. Teach., 2010, 32, 638645 .

7. Khan, K. and Ramachandran, S., Conceptual framework for performance assessment: competency, competence and performance in the context of assessments in healthcare-deciphering the terminology. Med. Teach., 2012, 34, 920-928.

8. Taber, S., Frank, J. R., Harris, K. A., Glasgow, N. J., Iobst, W. and Talbot, M., Identifying the policy implications of competency-based education. Med. Teach., 2010, 32, 687-691.

9. McMullan, M., Endacott, R. and Gray, M. A., Portfolios and assessment of competence: a review of the literature. $J$. $A d v$. Nurs., 2003, 41, 283-294.

10. Mulder, M., Competence development: some background thoughts. J. Agric. Edu. Ext., 2001, 7(4), 147-159.

11. Hagger, H. and McIntyre, D., Learning Teaching from Teachers. Realizing the Potential of School-based Teacher Education, Open University Press, Maidenhead, UK, 2006.

12. Selvi, K., Teachers' competencies. Cultura: Int. J. Philos. Cult. Axiol., 2010, 7(1), 167-175.

13. Maria, L., The professional competencies of teachers: which qualities, attitude, skills and knowledge contribute to a teacher's effectiveness? Int. J. Hum. Soc. Sci., 2011, 1(21), 66-78.

14. Lauermnn, F. and Konig, J., Teachers' professional competence and wellbeing: understanding the links between general pedagogical knowledge, self-efficacy and burnout. Learn. Instr., 2016, 45, 9-19.
15. Adnan, S. S. Nurkamto, J. and Setiawan, B., Teacher competence in authentic and integrative assessment in Indonesian language learning. Int. J. Instr., 2019, 12(1), 701-716.

16. Chong, S. N. Y. and Cheah, H. M., A values, skills and knowledge framework for initial teacher preparation programmes. Aust. J. Teach. Educ., 2009, 34(3), 1-17.

17. Gabrys-Barker, D., On teacher beliefs, self-identity and the stages of professional development. Linguarum Arena, 2010, 1(1), 2542.

18. Bhargava, A. and Pathy, M., Perception of student teachers about teaching competencies. Am. Int. J. Contemp. Res., 2011, 1(1), 7781.

19. Vijaykumar, M. S., The influence of teacher's professional competence on students' achievement. IOSR J. Eng., 2013, 3(11), 2278-8719.

20. Barnes, A. E., Boyle, H., Zuilkowski, S. S. and Bello, Z. N., Reforming teacher education in Nigeria: laying a foundation for the future. Teach. Teach. Educ., 2019, 79, 153-163.

21. Marcut, I. G. and Kifor, S., How did I become a good teacher? implications for teacher education. In 8th Balkan Regional Conference on Engineering and Business Education and 10th International Conference on Engineering and Business Education, Sibiu, Romania, October 2017, vol. 3(1), pp. 223-232.

22. Glaesser, J., Competence in educational theory and practice: a critical discussion. Oxford Rev. Educ., 2019, 45(1), 70-85.

23. Kunter, M., Klussman, U., Baument, J., Richter, D., Voss, T. and Hachfeld, A., Professional competence of teachers: effects on instructional quality and student development. J. Educ. Psychol., 2013, 105(3), 805-820.

24. Bohlouli, M., Nikolao, M. and George, K., Competence assessment as an expert system for human resource management, a mathematical approach. Expert Syst. Appl., 2017, 70, 83-102.

25. Dineke, E. H. T., Dolmans, D. H. J. M., Wolf Hagen, I. H. A. P. and Vleuten, V. D., The development and validation of a framework for teaching competencies in higher education. Higher Educ., 2004, 48, 253-268.

26. Roelofs, E. and Sanders, P., Towards a framework for assessing teacher competence. Eur. J. Vocat. Train., 2007, 40(1), 123-139.

27. Hayes, D., Chang, K. and Jeon, Y. J., Competency frameworks and implications for teacher assessment. Adv. Sci. Lett., 2017, 23(10), 9778-9782.

28. Francesca, C., Teacher competence frameworks in Europe: policy as discourse and policy as practice. Eur. J. Educ., 2014, 49(3), $311-331$.

29. Tamboli, P. M. and Nene, Y. L., Modernizing higher agricultural education system in India to meet the challenges of 21 st century. Asian Agric-Hist., 2013, 17(3), 251-264.

30. Garton, B. L. and Chung, N., The in-service needs of beginning teachers of agriculture as perceived by beginning teachers, teacher educators and state supervisors. J. Agric. Educ., 1996, 37(3), 5258.

31. Nesbitt, D. L. and Mundt, J. P., An evaluation of the University of Idaho beginning agriculture teacher induction program. J. Agric. Educ., 1993, 34(2), 11-17.

32. Edwards, M. C. and Briers, G. E., Assessing the in-service needs of entry-phase agriculture teachers in Texas, a discrepancy model versus direct assessment. J. Agric. Educ., 1999, 40(3), $40-49$.

33. Garton, B. L. and Chung, N., An assessment of the in-service needs of beginning teachers of agriculture using two assessment models. J. Agric. Educ., 1997, 38(3), 51-58.

34. Layfield, D. K. and Dobbins, T. R., In-service needs and perceived competencies of South Carolina agricultural educators. J. Agric. Educ., 2002, 43(4), 46-55.

35. Newman, M. E. and Johnson, D. M., In-service education needs of teachers of pilot agri-science courses in Mississippi. J. Agric. Educ., 1994, 35(1), 54-60. 
36. Peake, J. B., Duncan, D. W. and Ricketts, J. C., Identifying technical content training needs of Georgia agriculture teachers. J. Career Tech. Educ., 2007, 23(1), 44-45.

37. Conklin, N. L., Hook, L. L., Kelbaugh, B. J. and Nieto, R. N., Examining a professional development system. A comprehensive needs assessment approach. J. Extens. (on-line), 2002, 40(5) Article 5FEA1; available at: http://www.joe.org/joe/2002 october/a1.php

38. Waters, R. G. and Haskell, L. J., Identifying staff development needs of cooperative extension faculty using a modified Borich needs assessment model. J. Agric. Educ., 1989, 30(2), 26-32.

39. National Association of Agricultural Educators, What is agricultural education? 2019; https://www.naae.org/whatisaged/

40. Phipps, L. J. and Osborne, E. W., Handbook on Agricultural Education in Public Schools, The Interstate Printers and Publishers, Inc. 1988, Danville, IL, USA, 5th edn.

41. American Association for Agricultural Education, National standards for teacher education in agriculture, 2001; http://aaae. okstate.edu/Reports/ncatestds.pdf

42. Roberts, T. G., Doole, K. E., Harlin, J. F. and Murphrey, T. P., Competencies and traits of successful agricultural science teachers. J. Career Tech. Educ., 2006, 22(2), 1-11.

43. Harder, A., Roberts, T. G., Stedman, N. L., Thoron, A. and Myers, B. E., An analysis of the teaching competencies of agricultural and life sciences faculty. NACTA J., 2009, 53(4), 49-55.

44. Kiumars, Z. and Baygi, A. H., What can a Borich needs assessment model tell us about in-service training needs of faculty in a college of agriculture? The case of Iran. J. Agric. Educ. Extens., 2008, 14(4), 347-357.

45. ICAR, Agricultural Education Portal, Indian Council of Agricultural Research, New Delhi, India, 2019; https://education. icar.gov.in/.

46. Indian Agricultural Universities Association, Strength of staff and students of IAUA, 2019; www.iauaindia.org/Introduction/htm

47. NAAS, Redefining agricultural education and extension system in changed scenario. Policy Paper No. 31, National Academy of Agricultural Sciences, New Delhi, 2005, p. 8.

48. Challa, J., Joshi, P. J. and Tamboli, P. M., Revitalizing higher agricultural education in India. Issues and challenges. Econ. Polit. Wkly, 2011, 46, 326-329.

49. Institutional Management in Higher Education, Learning our lesson: review of quality teaching in higher education, 2009; https://www.oecd.org/education/imhe/44058352.pdf
50. DET, Competency framework for teachers, Department of Education and Training, East Perth, Western Australia, 2004; http://det. wa.edu.au/policies/detcms/policy-planning-and-accountability/ policies-framework/guidelines/competency-framework-for-teachers. en?cat-id=3457997

51. Advisory Committee on Teacher Education and Qualifications, Towards a learning profession. The teacher competencies framework and continuing professional development of teachers. Education and Manpower Bureau, Hong Kong, 2003; https://www. edb.gov.hk/attachment/en/teacher/qualification-training-development/development/cpd-teachers/ACTEQ\%20Document $\% 202003$ \%20-\%20Eng.pdf

52. Rama Rao, D., Muralidhar, U. and Kalla, J. C., Profile of scientific staff in agricultural universities in India. Eur. J. Agric. Educ. Ext., 1997, 3(2), 119-129.

53. Ramesh, P. and Reddy, K. M., Teaching aptitude and personality type of faculty members of agricultural universities. J. Psychol. Res., 2015, 59(1), 29-35.

54. Thammi Raju, D., Ramesh, P., Murthy, G. R. K. and Senthil Vinayagam, S., Teaching competencies of newly recruited faculty of agricultural universities. J. Indian Educ., 2017, 43(2), 25-35.

55. Ramesh, P., Reddy, K. M., Rao, R. V. S., Dhandapani, A., Siva, G. S. and Ramakrishna, A., Academic achievement and personality traits of faculty members of Indian agricultural universities: their effect on teaching and research performance. J. Agric. Educ. Ext., 2017, 23(1), 79-94.

56. Ramesh, P., Thammi Raju, D., Reddy, K. M., Krishnan, P., Biswas, A. and Umamaheswari, T., Perception of teaching competencies by administrators, faculty and students of Indian agricultural universities: an assessment of faculty training needs. J. Agric. Educ. Ext., 2019, 25(4), 337-359.

57. Ramesh, P., Research attitude of entry level Indian agricultural scientists and its implications. Int. J. Agric. Sci., 2018, 10(22), 7498-7500.

58. Myers, B. E., Dyer, J. E. and Washburn, S. G., Problems facing beginning agriculture teachers. J. Agric. Educ., 2005, 46(3), 4755 .

Received 25 May 2019; accepted 12 October 2019

doi: $10.18520 / \mathrm{cs} / \mathrm{v} 118 / \mathrm{i} 3 / 356-361$ 